\title{
Investigating the relationship between employees' career anchors and their psychosocial employability attributes in a financial company
}

\author{
Authors: \\ Rudolf M. Oosthuizen \\ Melinde Coetzee ${ }^{1}$ \\ Fezeka Mntonintshi ${ }^{1}$ \\ Affiliations: \\ ${ }^{1}$ Department of Industrial \\ and Organisational \\ Psychology, University of \\ South Africa, South Africa \\ Correspondence to: \\ Rudolf Oosthuizen \\ Email: \\ oosthrm@unisa.ac.za \\ Postal address: \\ PO Box 392, University of \\ South Africa 0003, \\ South Africa \\ Dates: \\ Received: 22 May 2014 \\ Accepted: 18 July 2014 \\ Published: 28 Oct. 2014 \\ How to cite this article: \\ Oosthuizen, R.M., Coetzee, \\ M., \& Mntonintshi, F. \\ (2014). Investigating the \\ relationship between \\ employees' career anchors \\ and their psychosocial \\ employability attributes \\ in a financial company. SA \\ Journal of Human Resource \\ Management/SA Tydskrif vir \\ Menslikehulpbronbestuur, \\ 12(1), Art. \#650, 10 pages. \\ http://dx.doi.org/10.4102/ \\ sajhrm.v12i1.650

\section{Copyright:} \\ (C) 2014. The Authors. \\ Licensee: AOSIS \\ OpenJournals. This work \\ is licensed under the \\ Creative Commons \\ Attribution License.
}

Read online:

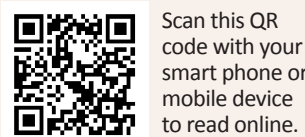

Orientation: The challenge of sustaining one's employability in a highly dynamic and turbulent labour market places new demands on individuals' ability to navigate their career development. Career management practices in organisations should help individuals gain awareness of the career meta-capacities they need to sustain their employability.

Research purpose: The objective of the study was to investigate the relationship between employees' career anchors and their psychosocial employability attributes as important career meta-capacities in contemporary career development. The study also investigated whether individuals from different age and race groups differed significantly regarding these career meta-capacities.

Motivation for the study: Career management has become essential in the contemporary workplace for employees to sustain their employability. Research points to the importance of psychosocial career meta-capacities in helping employees to manage their career development and employability.

Research design, approach and method: A cross-sectional quantitative survey using primary data was conducted on a non-probability purposive sample $(N=108)$ of full-time employees (67\% women; $78 \%$ 26-45 years old; $78 \%$ black employees) at a South African financial company. Correlations and Scheffé's post-hoc test were performed to achieve the research objectives.

Main findings: Significant positive relationships were observed between the participants' career anchors and their psychosocial employability attributes. Age and race groups differed significantly only in terms of their career anchors.

Practical/managerial implications: Career management practices in the organisation should accommodate the differences in career orientations and how these relate to the psychosocial employability attributes of their employees.

Contribution: The findings add potentially important insights that may inform human resource practices aimed at enhancing the career development and employability of employees and addressing the career needs of different age and race groups.

\section{Introduction}

\section{Key focus}

Proactive career management has become essential in the contemporary workplace for employees to sustain their employability (Bezuidenhout, 2011; Chudzikowski, 2012; Schreuder \& Coetzee, 2011; Tones, Pillay \& Kelly, 2011), especially in the financial sector (Joāo \& Coetzee, 2011). The financial sector is recognised for its quest to attract, retain and develop talent from diverse groups of people due to global and national skills shortages in this sector (DHET, 2014; Joāo \& Coetzee, 2011; Pato \& Spira, 2008; South African Institute of Chartered Accountants [SAICA], 2008). Hillage and Pollard (1998) view employability as the capacity of an individual to gain initial employment, to maintain employment and to move self-sufficiently within the labour market. The challenge of sustaining one's employability in a highly dynamic and turbulent labour market with unclear career paths places new demands on employees' ability to navigate their career development (Savickas \& Porfeli, 2012; Van der Heijde, 2014). Research points to the importance of psychosocial career meta-capacities in helping employees to manage their career development and employability (Coetzee, 2014; Savickas \& Porfeli, 2012; Stauffer, Maggiori, Froidevaux \& Rossier, 2014; Tones et al., 2011). Career management practices in organisations should help individuals gain awareness of the career meta-capacities they need to sustain their employability (Nazar \& Van der Heijden, 2012; Schreuder \& Coetzee, 2011; Van der Heijde, 2014). In this regard, the present study focuses on the constructs of career anchors (Schein, 1990) and psychosocial 
employability attributes (Bezuidenhout, 2011), which have been recognised in the research literature as important psychosocial career meta-capacities in contemporary career development (Coetzee \& Schreuder, 2014; Potgieter, 2012, 2014).

\section{Background to the study}

Research on the relationship between individuals' career self-concept and their self-perceived employability has increased in importance in the light of the more turbulent and uncertain nature of individuals' career paths (Chudzikowski, 2012; Nazar \& Van der Heijden, 2012). In terms of career management and development, work is seen as an important context for the expression of one's self (Nazar \& Van der Heijden, 2012). Edgar Schein's seminal work on career anchors emphasises the development of a stable career selfconcept or identity (which he termed the 'career anchor') in career decision-making and management (Feldman \& Bolino, 1996; Schein, 1990). Schein's $(1978,1992)$ research on the career anchors of employees suggests that individuals' true career-related abilities, needs and values become crystallised through a variety of real-work experiences. Research by Beyer and Hanna (2002) as well as Nazar and Van der Heijden (2012) corroborates this view by suggesting that the career identity develops in the context of the workplace and the work experiences that give individuals the chance to enact a variety of roles and explore different identities, which add more complexity to their identities in terms of roles, interests and abilities. Work experiences facilitate the integration of individuals' interests with their abilities, preferences and values and, as a consequence, a stable career identity as expressed by people's career anchors (Coetzee \& Schreuder, 2014; Feldman \& Bolino, 1996).

Coetzee and Schreuder (2014) view people's career anchors as important career meta-capacities in contemporary career development. Career meta-capacities denote individuals' career-related psychological capital and social resources and strengths that enable them to be self-directed learners and proactive agents in the construction and design of their careers and employability in the contemporary turbulent occupational world (Coetzee, 2014; Savickas \& Porfeli, 2012). Ndzube (2013) notes that in the volatile labour market conditions of the 21st century, the external career is bound to take different shapes and forms and individuals may be forced to take decisions that have not been carefully considered. Ndzube further argues that individuals need a deeper sense of career identity and self-awareness to enact appropriate career choices under these conditions. The career anchor develops in the process of career development and enables the careerist to make choices congruent with the individual's career identity (Ndzube, 2013; Schein, 1990). Career anchors are thus seen to lead to a deeper self-awareness and a clear career identity (Ellison \& Schreuder, 2000; Ndzube, 2013).

The career identity is seen as an important aspect of individuals' self-perceived employability and their expectations for the future. Nazar and Van der Heijden (2012) purport in this regard that individuals with well-crystallised career identities relating to their personal career preferences, motives and values appear to be psychologically free from the boundaries of organisational and group constraints, and better able to adjust to changing career circumstances and sustain their future employability. Research indicates a significant relationship between individuals' self-esteem or self-concept and their employability (Pool \& Sewell, 2007), and psychosocial employability attributes such as career self-management, career resilience, sociability and proactivity (Potgieter, 2012, 2014). However, it is not clear from the research how Schein's (1978, 1990, 1992) notion of career anchors relates to other career meta-capacities such as people's psychosocial employability attributes. The present study, therefore, focused on this relationship to add to the extant career research literature.

Individuals' age and race were also of specific relevance to the present research due to the importance of these characteristics in today's generationally and racially diverse organisational context. Age is an important concept in career development research (Super, 1990) whilst research on the subjective work experiences of different racial groups in the post-apartheid South African organisational context has increased in importance (Coetzee \& Bergh, 2009; Coetzee \& Schreuder, 2009; Themba, Oosthuizen \& Coetzee, 2012). Research shows that person-related characteristics such as age and race may influence individuals' employability (Clarke, 2008). Age relates to specific life and career stages and the differences in psychological vocational development tasks individuals need to deal with in their career development (Schein, 1990; Super, 1990). Individuals under the age of 25 are regarded as in their early life and career stage and generally harbour career preoccupations relating to the personal freedom to explore life and career possibilities (Coetzee \& RoythorneJacobs, 2012; Super, 1990). Individuals between the ages of 26 and 45 are generally regarded to be in the establishment life and career stage. Typical career preoccupations include settling down in one's career, working to make one's place in a chosen field of work, thinking about the job on a long-term basis and advancing in one's work, job and career (Coetzee \& Roythorne-Jacobs, 2012; Super, 1990). Individuals older than 45 are seen to be in the maintenance (45-65) and retirement $(\geq 65)$ phases of their lives and careers. They are either preoccupied with updating their skills and adjusting to new technology to maintain their positions (45-65) or preparing for retirement ( $\geq 65$ ) (Coetzee \& Roythorne-Jacobs, 2012; Super, 1990). In terms of age and race differences, previous research indicated differences in career anchors (Coetzee \& Schreuder, 2008) and psychosocial employability attributes (Botha, 2014). Understanding the diverse career-related needs of individuals from different ages or life and career stages and those from different race groups has also increased in importance in the light of the multicultural South African work environment (Coetzee \& Schreuder, 2008). The present research, therefore, also explored the differences between these groups in terms of their career anchors and psychosocial employability attributes. 


\section{Literature review}

\section{Career anchors}

Schein's $(1990,1996)$ notion of career anchors is regarded as an important meta-capacity in contemporary career development (Coetzee \& Schreuder, 2014). Individuals' constellations of self-perceived talents and abilities (based on actual successes in a variety of real-work settings), self-perceived motives and needs (based on actual experiences with a variety of job assignments) and self-perceived attitudes and values (based on reactions to a variety of norms and values encountered in different work groups and organisations) describe their dominant career anchors and stabilise their career decisions in predictable ways (Chang, Jiang, Klein \& Chen, 2012; Feldman \& Bolino, 1996; Schein, 1990).

Schein (1990) differentiates between eight career anchors as described below (Chang et al., 2012; Feldman \& Bolino, 1996):

- Career anchors that focus on the expression of workrelated talents:

- Technical or functional competence: The individual is primarily motivated by the need to exercise technical and functional expertise.

- General managerial competence: The individual is primarily motivated by the need to pursue higher managerial levels and greater responsibility to determine policymaking.

- Entrepreneurial creativity: The individual is primarily motivated by the need to build or create something that is entirely one's own project.

- Career anchors that focus on structuring one's work roles consistent with basic personal desires and personal life:

- Autonomy and independence: The individual is primarily motivated to seek work situations that are maximally free of organisational constraints.

- Security and stability: The individual is primarily motivated by job security and long-term attachment to one organisation.

- Lifestyle: The individual is primarily motivated to balance career with lifestyle.

- Career anchors that focus on individuals' identification with their occupations and the cultures of their organisation:

- Service or dedication to a cause: The individual is primarily motivated to help others and improve the world in some fashion.

- Pure challenge: The individual is primarily motivated to overcome obstacles, conquer difficult tasks or problems and to overwhelm competitors.

Wils, Wils and Tremblay (2010) found the eight career anchors to be significantly related to specific work values such as openness to change (pure challenge, entrepreneurial creativity and autonomy and independence), selftranscendence (technical competence and service or dedication to a cause), self-enhancement (managerial competence) and conservation (security and stability and lifestyle). The motivational domains underpinning these work values can be either compatible or mutually inconsistent and may influence career decisions (Coetzee \& Schreuder, 2014).

Coetzee and Schreuder (2011) also found positive associations between the career anchors and people's self-perceived employability. As a career meta-capacity, the career anchor is seen as an internal resource that functions as a set of driving and constraining forces on individuals' career decisions and choices (Coetzee \& Schreuder, 2014). Based on their career anchors, individuals will either be attracted to, or pulled back into, environments more congruent with the stable selfconcept or career identity represented by the career anchor (Chang et al., 2012; Feldman \& Bolino, 1996). Career-related change, growth and movement will occur within some circumscribed area and will not be random (Feldman \& Bolino, 1996). Research suggests that, apart from a dominant career anchor, individuals may also have secondary (second preferred anchor) and tertiary (third preferred career anchor) career anchors, which may enable them to adapt to changing career circumstances (Coetzee \& Schreuder, 2008, 2014; Feldman \& Bolino, 1996; Schein, 1990).

In terms of age, Coetzee and Schreuder (2008) found that individuals aged 25 and younger are significantly more driven by their personal needs in terms of their career anchors than their older counterparts, showing a strong preference for the autonomy and independence career anchor. Individuals aged 26 and older showed a higher preference for the service or dedication to a cause, pure challenge and managerial competence career anchors than their younger counterparts. Coetzee and Schreuder further found that coloured, Indian and white people had a stronger preference for the entrepreneurial creativity career anchor than black Africans.

\section{Psychosocial employability attributes}

Psychosocial career meta-capacities are seen to act as key transactional resources between the inner (psychological) and external (social) worlds of a person in the management of one's employability (Coetzee, 2014; Savickas \& Porfeli, 2012). These meta-capacities are regarded as important for proactive career behaviour and essential for sustaining one's employability in the contemporary employment market (Bezuidenhout, 2011; Botha, 2014; Coetzee, 2014; Potgieter, 2012, 2014).

Bezuidenhout (2011) identified a range of psychosocial career meta-capacities that she termed essential 'employability attributes' in the management of employability. These attributes include psychosocial meta-capacities relating to the career (career self-management, career resilience and entrepreneurial orientation), intrapersonal (proactivity, selfefficacy and emotional literacy) and interpersonal (sociability and cultural competence) behavioural domains of an individual (Botha, 2014). The career meta-capacities that relate to these three behavioural domains are outlined below. 
Attributes relating to the individual's career behaviour: Career self-management is regarded as important for career development (Pool \& Sewell, 2007) and includes attributes relating to the willingness to set career goals, reflect on them, identify the competencies required to achieve them and implement appropriate actions to achieve these career goals (Botha, 2014). Career resilience refers to the ability to bounce back and to demonstrate a high degree of adaptability, flexibility, self-confidence and competence regardless of adverse career circumstances (Bezuidenhout, 2011). Fugate and Kinicki (2008) found resilient individuals to have positive self-evaluations and optimism about and confidence in their capacity to handle challenges and future events. Entrepreneurial orientation refers to the ability to create employment by taking advantage of career opportunities and profiting from one's own connections and skills (Bezuidenhout, 2011). Obschonka (2014) regards entrepreneurial skills as essential for sustaining one's employability.

Attributes relating to the individual's intrapersonal behaviour: Proactivity denotes active role orientations and future-oriented and self-initiated action to change and improve oneself and one's career situation (Bezuidenhout, 2011). A proactive personality has been positively related to active adaptability and employability (Mihail, 2008; Van der Heijde \& Van der Heijden, 2006). Self-efficacy entails the belief in one's capabilities to cope with a range of challenging or stressful demands in a variety of contexts (Bezuidenhout, 2011). Efficacy beliefs have been related to employability, career satisfaction and positive career development (Pool \& Sewell, 2007; Van der Heijde \& Van der Heijden, 2006). Emotional literacy refers to the adaptive use of emotions in the management of one's career (Bezuidenhout, 2011). Research also indicates a positive association between individuals' emotional intelligence and their self-perceived employability (Coetzee \& Schreuder, 2011; Pool \& Sewell, 2007).

Attributes relating to the individual's interpersonal behaviour: Sociability encompasses networking behaviours and openness for building social contacts and networks in the advancement of one's career (Bezuidenhout, 2011). Successful networking has been related to increased job opportunities, career advancement and satisfaction (Forret \& Sullivan, 2002). Cultural competence refers to the ability to use knowledge about other cultures and their customs, beliefs, interaction rules and values to build positive intercultural relations in the workplace (Bezuidenhout, 2011).

Although there is a dearth of research on the relationship between Schein's (1990) construct of career anchors and Bezuidenhout's (2011) set of employability attributes, Ndzube (2013) proposes certain theoretical similarities between these two constructs. These theoretical similarities are summarised in Table 1 . Both constructs relate to an enhanced self-awareness of one's capacities in managing one's career development in the contemporary employment context. Career anchors and psychosocial employability attributes facilitate the development of individuals' career identity or self-concept and guide the setting of clear career goals and career decisions (Bezuidenhout, 2011; Ndzube, 2013; Schein, 1990, 1996). It was, therefore, expected that individuals' career anchors would relate positively and significantly to their psychosocial employability attributes.

There appears to be limited research on the differences between age and race groups on the psychosocial employability attributes postulated by Bezuidenhout (2011). This may be attributed to the fact that research on individuals' employability attributes in the South African organisational context is limited (Bezuidenhout, 2011). In terms of age, Botha (2014) found older employees to have higher self-perceptions of their self-efficacy than their younger counterparts. Her research suggests further that white people tend to obtain lower scores than other race groups on cultural competence and sociability.

\section{Research objective}

The objective of the study was to investigate the relationship between employees' career anchors and their psychosocial employability attributes as important career meta-capacities in contemporary career development. The study also explored whether individuals from different age and race groups differed significantly regarding these career meta-capacities.

\section{Potential for added value}

The findings may potentially contribute important insights that may inform human resource practices aimed at enhancing the career development and employability of employees. Understanding the career anchors and employability attributes of different age and race groups may further contribute to career development support interventions for these groups.

\section{What follows}

The next section outlines the research design. The results are then reported and discussed.

\section{Research design Research approach}

A cross-sectional quantitative research approach was adopted for the purposes of this study because the study was limited to a single financial company at a certain point in time.

\section{Research method \\ Participants}

The population was 180 individuals employed in a single financial organisation. Non-probability purposive sampling was used. The survey yielded a final sample of 108 useable questionnaires $(60 \%$ response rate). Women represented $67 \%$ of the sample. The sample comprised participants at managerial level (31\%) and staff level (69\%) positions. In terms of age, the sample was represented by participants of 25 years or younger $(21 \%)$ and those aged between 26 and 45 (78\%). The racial groups constituted $49 \%$ black African, $10 \%$ 
TABLE 1: Theoretical similarities between the constructs of career anchors and psychosocial employability attributes.

\begin{tabular}{lll}
\hline Common characteristics & Career anchors & Psychosocial employability attributes \\
\hline Enhance self-awareness & $\begin{array}{l}\text { Through years of work experience an individual gains awareness of } \\
\text { skills, interests and abilities. }\end{array}$ & $\begin{array}{l}\text { Facilitate positive self-evaluations regarding one's capability in } \\
\text { managing and sustaining one's employability. }\end{array}$ \\
$\begin{array}{ll}\text { Develop career identity } \\
\text { real-work organisation. }\end{array}$ & $\begin{array}{l}\text { Individuals are guided by their anchors in choosing careers that will } \\
\text { be congruent and thus satisfying. }\end{array}$ & $\begin{array}{l}\text { Individuals continuously study the job market and align personal } \\
\text { employers } \\
\text { skills and competencies accordingly, and make job choices that will } \\
\text { enhance their employability. }\end{array}$ \\
Suide career decision-making & $\begin{array}{l}\text { Knowing one's anchor does not imply absolute rigidity and zero } \\
\text { change; instead it implies some movement, not random movement, } \\
\text { however, but movement within a circumscribed area. }\end{array}$ & $\begin{array}{l}\text { Being employable increases the chances of relatively stable career } \\
\text { movement, even in a jobless labour market. }\end{array}$ \\
Career goal clarity & $\begin{array}{l}\text { The dominant anchor influences one's career track. Individuals are } \\
\text { able to focus, move and grow within a specified career. }\end{array}$ & $\begin{array}{l}\text { Individuals set clear and measurable career goals to meet the } \\
\text { challenges of the labour market and to remain employable. }\end{array}$ \\
\hline
\end{tabular}

Source: Adapted from Ndzube, F. (2013). The relationship between career anchors and employability. Unpublished master's dissertation, Department of Industrial and Organisational Psychology, University of South Africa, Pretoria, South Africa

mixed race, $19 \%$ Indian and $21 \%$ white people.

\section{Measuring instruments}

The Career Orientations Inventory (COI) developed by Schein (1990) and the Employability Attributes Scale (EAS) developed by Bezuidenhout and Coetzee (2011) were used to assess the participants' career anchors and psychosocial employability attributes. A biographical questionnaire was also included.

The COI (Schein, 1990) measures respondents' career anchor orientations on a six-point Likert-type scale $(1=$ never true for me; 6 always true for me) and consists of 40 items in total: five technical or functional competence items (e.g. 'I will feel successful in my career only if I can develop my technical or functional skills to a very high level of competence'), five general managerial competence items (e.g. 'I dream of being in charge of a complex organisation and making decisions that affect many people'), five entrepreneurial creativity items (e.g. 'Building my own business is more important to me than achieving a high-level managerial position in someone else's organisation'), five autonomy and independence items (e.g. 'I am most fulfilled in my work when I am completely free to define my own tasks, schedules and procedures'), five security and stability items (e.g. 'I would rather leave my organisation altogether than accept an assignment that would jeopardise my security in that organisation'), five lifestyle items (e.g. 'I dream of a career that will permit me to integrate my personal, family and work needs'), five service or dedication to a cause items (e.g. 'I am most fulfilled in my career when I have been able to use my talents in the service of others') and five pure challenge items (e.g. 'I will feel successful in my career only if I face and overcome very difficult challenges'). The COI has shown good psychometric validity and reliability in other South African multicultural samples (Coetzee \& De Villiers, 2010; Coetzee, Schreuder \& Tladinyane, 2007). Acceptable internal consistency reliability coefficients (Cronbach's alpha) ranging between 0.64 (technical or functional competence) and 0.79 (entrepreneurial creativity) were obtained for the present study.

The EAS (Bezuidenhout \& Coetzee, 2011) measures respondents' responses on a six-point Likert-type scale
( $1=$ never; 6 = always $)$ and consists of 56 items in total: 11 career self-management items (e.g. 'I know what I must do to make a success of my career'), six career resilience items (e.g. 'I anticipate and take advantage of changes in my career environment'), seven entrepreneurial orientation items (e.g. 'I continuously look into new business opportunities'), seven proactivity items (e.g. 'I spend a lot of time enhancing my knowledge and skills to benefit my career'), six self-efficacy items (e.g. 'When I achieve something, it is because of my own effort'), seven emotional literacy items (e.g. 'I can easily understand why I feel a certain way'), seven sociability items (e.g. 'I can use my networks to find new job opportunities') and five cultural competence items (e.g. 'I can easily initiate and maintain relationships with people from different cultures'). Similar to the COI, the EAS has evidenced good psychometric validity and reliability in other South African multicultural samples (Botha, 2014; Potgieter, 2012). Acceptable internal consistency reliability coefficients (Cronbach's alpha) ranging between 0.74 (sociability) and 0.90 (career self-management) were obtained for the present study.

\section{Research procedure}

Ethical clearance to conduct the research was obtained from the Ethics Committee of the research institution. The management of the organisation in which the study was conducted provided permission for the study. The questionnaires were manually distributed to the participants. An informed consent form was attached for the participants to sign and return for record keeping and to meet ethical requirements. Thereafter, group sessions were held for the completion of the questionnaires which took on average about $20 \mathrm{~min}$. One of the researchers collected the questionnaires from the participants during the group sessions. Other ethical considerations included honouring confidentiality, voluntary participation and utilising the results for broad group-based research purposes only. Individual feedback was provided at the request of the participants.

\section{Statistical analysis}

The IBM Social Package for Social Sciences Version 22.0 was used to analyse the data. The statistical analysis involved computing descriptive statistics (means, standard deviations and internal consistency reliability coefficients) and correlations to assess the relationship between the 
participants' career anchors and psychosocial employability attributes. To assess whether the age and race groups differed significantly regarding their career anchors and psychosocial employability attributes, Wilks's lambda and Scheffé's posthoc tests were applied in order to determine the source of differences. To counter the probability of a type I error, the significance value was set at the $95 \%$ confidence interval level $(p \leq 0.05)$.

\section{Results \\ Descriptive statistics}

Table 2 shows that the participants obtained the highest mean scores on the following three career anchors: pure challenge (mean $=4.44 ; \mathrm{SD}=0.98)$, technical or functional competence (mean $=4.42 ; \mathrm{SD}=0.88)$ and service or dedication to a cause $($ mean $=4.37 ; \mathrm{SD}=0.84)$. The participants obtained the lowest mean score on the general managerial competence career anchor (mean $=3.50 ; \mathrm{SD}=0.98)$. In terms of the EAS, the participants obtained relatively high mean scores for all eight psychosocial employability attributes. The highest mean scores were obtained for career self-management (mean $=4.78 ; \mathrm{SD}=0.83)$ and entrepreneurial orientation $($ mean $=4.75 ; \mathrm{SD}=0.82)$. They obtained the lowest mean score on sociability $($ mean $=4.36$; $\mathrm{SD}=0.83)$.

\section{Correlations}

As shown in Table 3, significant and positive correlations of small $(r \leq 0.29)$ and large $(r \geq 0.50)$ practical effects were obtained between almost all the career anchors and psychosocial employability attributes. The technical or functional competence, security and stability and lifestyle career anchors did not relate significantly to the cultural competence attribute. The strongest correlations (large practical effect) were observed between the following variables: the service or dedication to a cause career anchor and career self-management $(r=0.52 ; p \leq 0.01)$, self-efficacy $(r=0.55 ; p \leq 0.01)$, career resilience $(r=0.51 ; p \leq 0.01)$, entrepreneurial orientation $(r=0.54 ; p \leq 0.01)$ and proactivity $(r=0.56 ; p \leq 0.01)$. Entrepreneurial creativity also had significant correlations of large practical effect with selfefficacy $(r=0.55 ; p \leq 0.01)$ and, as expected, entrepreneurial orientation $(r=0.53 ; p \leq 0.01)$. The pure challenge career anchor also showed significant correlations of large practical effect with self-efficacy $(r=0.52 ; p \leq 0.02)$ and entrepreneurial orientation $(r=0.52 ; p \leq 0.01)$.

\section{Scheffé's post-hoc test: Age and race differences}

The Wilks's lambda statistic showed significant differences between the age and race groups in terms of their career anchors only. These groups did not differ significantly regarding their psychosocial employability attributes.

In terms of age, the significant Scheffé's post-hoc test results summarised in Table 4 showed that the age group 26-45 obtained significantly higher mean scores than those younger than 25 on the technical or functional competence (mean difference $=-3.00 ; p=0.02$ ), autonomy and independence (mean difference $=-2.96 ; p=0.04$ ), lifestyle (mean difference $=-3.23 ; p=0.01$ ) and service or dedication to a cause (mean difference $=-2.78 ; p=0.02$ ) career anchors.

In terms of race, the significant Scheffé's post-hoc test results summarised in Table 5 showed the following differences: the black African participants obtained significantly higher mean scores than the Indian participants on the entrepreneurial creativity (mean difference $=-6.45 ; p=0.00$ ), autonomy and independence (mean difference $=-3.86 ; p=0.02$ ) and service or dedication to a cause (mean difference $=-3.55 ; p=0.01$ ) career anchors. The black African participants obtained significantly higher mean scores than the white participants on the security and stability career anchor (mean difference $=3.74 ; p=0.02$ ).

\section{Discussion}

The objective of the study was to explore the relationship between employees' career anchors and their psychosocial employability attributes as important career meta-capacities in contemporary career development. The study also explored whether individuals from different age and race groups differed significantly regarding these career meta-capacities.

\section{Relationship between career anchors and psychosocial employability attributes}

Overall, the results showed significant positive associations between the eight career anchors and the psychosocial employability attributes. Of particular interest are those relationships with a large practical effect $(r \geq 0.50)$ and especially those between the three dominant career anchors of the participants (pure challenge, technical or functional competence and service or dedication to a cause) and the psychosocial employability attributes. The rationale for focusing in this section on only the three dominant career anchors that emerged for the participants is based on parsimony and research suggesting that, apart from a dominant career anchor, individuals may also have secondary and tertiary career anchors that may enable them to adapt to changing career circumstances (Coetzee \& Schreuder, 2008, 2014; Feldman \& Bolino, 1996; Schein, 1990). Moreover, the three career anchors relate well to the nature of the work typically encountered in the financial environment which is predominantly technical or functional competence and service oriented (Joāo \& Coetzee, 2011).

The pure challenge career anchor relates to individuals' identification with their occupations and the culture of the organisation (Feldman \& Bolino, 1996). The results suggested that the motivational driving force underpinning the pure challenge career anchor is positively associated with an entrepreneurial orientation and proactivity in particular. According to Bezuidenhout (2011), these two psychosocial employability attributes represent individuals' 
TABLE 2: Descriptive statistics - Means, standard deviations and internal consistency reliability coefficients.

\begin{tabular}{|c|c|c|c|c|}
\hline COI and EAS & Variable & Mean & SD & $\alpha$ \\
\hline \multirow[t]{8}{*}{ Career Orientations Inventory } & Technical or functional competence & 4.42 & 0.88 & 0.64 \\
\hline & General managerial competence & 3.50 & 0.98 & 0.68 \\
\hline & Entrepreneurial creativity & 3.98 & 1.13 & 0.79 \\
\hline & Autonomy and independence & 3.84 & 0.99 & 0.70 \\
\hline & Security and stability & 4.26 & 0.98 & 0.70 \\
\hline & Lifestyle & 4.30 & 0.92 & 0.70 \\
\hline & Service or dedication to a cause & 4.37 & 0.84 & 0.68 \\
\hline & Pure challenge & 4.44 & 0.98 & 0.70 \\
\hline \multirow[t]{7}{*}{ Employability Attributes Scale } & Career self-management & 4.78 & 0.83 & 0.90 \\
\hline & Career resilience & 4.53 & 0.85 & 0.78 \\
\hline & Entrepreneurial orientation & 4.75 & 0.82 & 0.83 \\
\hline & Proactivity & 4.66 & 0.78 & 0.82 \\
\hline & Self-efficacy & 4.71 & 0.85 & 0.82 \\
\hline & Emotional literacy & 4.49 & 0.93 & 0.89 \\
\hline & Cultural competence & 4.48 & 0.95 & 0.88 \\
\hline
\end{tabular}

COI, Career Orientations Inventory; EAS, Employability Attributes Scale; SD, standard deviation; $\alpha$, alpha.

TABLE 3: Correlations between career anchors and psychosocial employability attributes.

\begin{tabular}{|c|c|c|c|c|c|c|c|c|}
\hline Variable & $\begin{array}{l}\text { Technical or } \\
\text { functional } \\
\text { competence }\end{array}$ & $\begin{array}{l}\text { General } \\
\text { managerial } \\
\text { competence }\end{array}$ & $\begin{array}{l}\text { Entrepreneurial } \\
\text { creativity }\end{array}$ & $\begin{array}{l}\text { Autonomy and } \\
\text { independence }\end{array}$ & $\begin{array}{l}\text { Security and } \\
\text { stability }\end{array}$ & Lifestyle & $\begin{array}{l}\text { Service or } \\
\text { dedication } \\
\text { to a cause }\end{array}$ & Pure challenge \\
\hline $\begin{array}{l}\text { Career self- } \\
\text { management }\end{array}$ & $0.39 * *$ & $0.38 * *$ & $0.41^{* *}$ & $0.21 *$ & $0.38 * *$ & $0.29 * *$ & $0.52^{* *}$ & $0.49 * *$ \\
\hline Career resilience & $0.39 * *$ & $0.44 * *$ & $0.46 * *$ & $0.33^{* *}$ & $0.21^{*}$ & $0.29 * *$ & $0.51^{* *}$ & $0.39 * *$ \\
\hline $\begin{array}{l}\text { Entrepreneurial } \\
\text { orientation }\end{array}$ & $0.43 * *$ & $0.45^{* *}$ & $0.53^{* *}$ & $0.33^{* *}$ & $0.25 * *$ & $0.35^{* *}$ & $0.54^{* *}$ & $0.52 * *$ \\
\hline Proactivity & $0.43 * *$ & $0.42 * *$ & $0.49 * *$ & $0.29 * *$ & $0.27^{* *}$ & $0.32 * *$ & $0.56^{* *}$ & $0.47 * *$ \\
\hline Self-efficacy & $0.47 * *$ & $0.48 * *$ & $0.55^{* *}$ & $0.43^{* *}$ & $0.36 * *$ & $0.41 * *$ & $0.55^{* *}$ & $0.52^{* *}$ \\
\hline Emotional literacy & $0.39 * *$ & $0.39 * *$ & $0.32 * *$ & $0.26 * *$ & $0.27 * *$ & $0.29 * *$ & $0.47 * *$ & $0.39 * *$ \\
\hline Sociability & $0.37 * *$ & $0.42 * *$ & $0.46^{* *}$ & $0.32 * *$ & $0.21 *$ & $0.31 * *$ & $0.46 * *$ & $0.37 * *$ \\
\hline Cultural competence & 0.18 & $0.43^{* *}$ & $0.38^{* *}$ & $0.29 * *$ & 0.15 & 0.18 & $0.39 * *$ & $0.32 * *$ \\
\hline
\end{tabular}

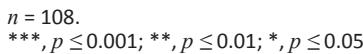

TABLE 4: Significant Scheffé's post-hoc test results - Age.

\begin{tabular}{lll}
\hline Variable & $p$ & \multicolumn{1}{c}{$\begin{array}{c}\text { Mean difference } \\
\text { ( } \mathbf{2 5} \text { years versus } \geq \mathbf{2 6 - 4 0} \text { years) }\end{array}$} \\
\hline Technical or functional competence & $0.02^{*}$ & -3.00 \\
Autonomy and independence & $0.04^{*}$ & -2.96 \\
Lifestyle & $0.01^{* *}$ & -3.23 \\
Service or dedication to a cause & $0.02 *$ & -2.78 \\
\hline
\end{tabular}

$n(\leq 25$ years $=23 ; 26-40$ years $=76)$.

${ }^{* * *}, p \leq 0.001 ;{ }^{* *}, p \leq 0.01 ;{ }^{*}, p \leq 0.05$. Wilks's lambda (Career Orientations Inventory) significant at $p=0.02$

TABLE 5: Significant Scheffé's post-hoc test results - Race.

\begin{tabular}{|c|c|c|c|c|}
\hline Variable & Cultural group I & Cultural group J & $p$ & Mean difference \\
\hline Entrepreneurial creativity & Indian & Black African & $0.00 * * *$ & -6.45 \\
\hline Autonomy and independence & Indian & Black African & $0.02 *$ & -3.86 \\
\hline Security and stability & Black African & White & $0.02 *$ & 3.74 \\
\hline Service or dedication to a cause & Indian & Black African & $0.01 * *$ & -3.55 \\
\hline
\end{tabular}

$n$ (black African $=53$; Indian $=21$; white $=23$ ).

${ }_{* * *}, p \leq 0.001 ;{ }^{* *}, p \leq 0.01 ; *, p \leq 0.05$. Wilks's lambda (Career Orientations Inventory) significant at $p=0.003$

ability to create employment by taking advantage of career opportunities and profiting from their own connections and skills (entrepreneurial orientation) and their belief in their capabilities to cope with a range of challenging or stressful demands in a variety of contexts (self-efficacy). The findings corroborate Wils et al.'s (2010) view that the pure challenge career anchor is motivated by having the openness to change and a sense of self-directedness. Individuals with a pure challenge career anchor are generally motivated to overcome obstacles and conquer difficult tasks or problems in the work environment (Schein, 1990). Coetzee and Schreuder (2011) found both the pure challenge and technical or functional competence career anchors to be positively associated with a concern for challenging opportunities to use, develop and demonstrate abilities and skills relating to one's employability. Similar to the pure challenge career anchor, the service or 
dedication to a cause career anchor relates to individuals' identification with their occupations and the culture of the organisation (Feldman \& Bolino, 1996). Individuals with a service or dedication to a cause career anchor are primarily motivated to help others and improve the world in some fashion (Schein, 1990). The results indicated in practical terms strong associations between this career anchor and the entrepreneurial orientation and self-efficacy attributes, including the career self-management, career resilience and proactivity attributes. Research in the South African financial environment also indicates an entrepreneurial orientation (Coetzee \& De Villiers, 2010) and confidence in career mobility opportunities due to the professional nature of the job or profession (Joāo \& Coetzee, 2011). The findings of the present study further support research by Coetzee and Schreuder (2011), which indicates a positive link between the service or dedication to a cause career anchor and individuals' employability beliefs, that is, the belief that they have the attributes, skills, knowledge, experience and occupational expertise to create or attract employment with ease. The career preoccupations underpinning the service or dedication to a cause career anchor may further explain the findings of the present research. The career concerns of this career anchor relate to opportunities to influence the employing organisation or social policies in the direction of one's personal values and involve the need to demonstrate skills and abilities in achieving one's goals (Coetzee \& Schreuder, 2011; Schein, 1990).

The technical or functional competence career anchor is motivated by the need to exercise one's work-related talents and improve one's technical and functional expertise (Feldman \& Bolino, 1996; Schein, 1990). However, in practical terms, the results showed only a moderate association between the technical or functional competence career anchor and the employability attributes of entrepreneurial orientation, self-efficacy, proactivity, career resilience and career self-management. This finding may be attributed to the primary motivational force underpinning the technical or functional competence career anchor, as also in the case with the service or dedication to a cause career anchor, being that of transcending one's own needs and contributing one's talents and expertise to the greater good of the whole (Wils et al., 2010).

\section{Differences between the age groups}

Overall, the results showed that the two age groups ( $\leq 25$ years and 26-45 years) did not differ significantly regarding their employability attributes. The two age groups only differed in terms of the technical or functional competence, autonomy and independence, lifestyle and service or dedication to a cause career anchors. The older age group showed a significantly higher preference for these career anchors than their younger counterparts. The findings are in agreement with research by Coetzee and Schreuder (2008), which shows individuals in the early life and career stage to have less strong preferences for the service or dedication to a cause and technical or functional competence career anchors than their older counterparts. However, the present findings are contrary to Coetzee and Schreuder's (2008) research, which shows the early life and career stage individual to have a stronger preference for the autonomy and independence career anchor than their older counterparts. The findings of the present study suggest that the participants in the establishment life and career stage (26-45 years) were more preoccupied than those in the early life and career stage ( $\leq 25$ years) with the expression of their work-related talents (technical or functional competence), structuring their work consistent with their basic personal desires and personal life (autonomy and independence and lifestyle) and identifying themselves strongly with their occupations and the culture of the organisation (service or dedication to a cause). These findings may be attributed to the typical career-related preoccupations associated with the establishment life and career stage, namely that of settling down in one's career and life, working to make one's place in a chosen field of work and thinking about the job on a long-term basis (Coetzee \& Roythorne-Jacobs, 2012; Super, 1990).

\section{Differences between the race groups}

Overall, the results showed that the four race groups (black African, mixed race, Indian and white) did not differ significantly regarding their employability attributes. The black, Indian and white participants only differed in terms of the entrepreneurial creativity, autonomy and independence, security and stability and service or dedication to a cause career anchors. The findings are contrary to research by Coetzee and Schreuder (2008), which indicates no significant differences between these race groups in terms of their career anchors. In terms of Wils et al.'s (2010) research on Schein's (1990) career anchors and Schwartz's (1992) work values, it appears that the black participants associated more strongly than the Indian participants with the motivational forces of openness to change and self-directedness (as underpinned by the entrepreneurial creativity and autonomy and independence career anchors) and self-transcendence (as underpinned by the service or dedication to a cause career anchor). The black participants also associated more strongly than their white counterparts with the motivational force of conservation (security and stability). These findings could be attributed to the current South African employment equity legislation favouring the advancement of black Africans in particular and the communal value system that black Africans subscribe to (Schreuder \& Coetzee, 2011). Joāo and Coetzee (2011) also found that professionals in the financial environment feel positive about career mobility opportunities, which may be enhanced for black people due to affirmative action legislation.

\section{Implications for practice}

The practical value of the research findings lies in the design of career management practices that are based on the associations found between the participants' career anchors and their psychosocial employability attributes. 
Organisational career management practices should strive to increase employees' self-awareness of their career anchors and how these relate to their ability to manage and sustain their employability (Ndzube, 2013). Career discussions should help employees understand their strengths and weaknesses in terms of the psychosocial employability attributes they require to sustain their employability (Potgieter, 2012, 2014) and how these relate to their career identities or self-concepts and the motivational forces (values) that underpin their primary, secondary and tertiary career anchors (Coetzee \& Schreuder, 2014).

Career management practices should also consider the differences observed between the age and race groups in terms of their career anchors. The different career-related needs and motivations of employees in the early life and career stage and establishment life and career stage and the black African, Indian and white employees in the organisation who participated in this study could be used to inform career discussions. Such career discussions could focus on helping these groups understand how their career anchors influence their career decisions and how their career anchors relate to their capacity to manage their career development and employability (Coetzee \& Schreuder, 2014; Ndzube, 2013).

\section{Limitations and recommendations for future research}

The discussion of the meaning of the results and potential implications of the findings must take into consideration the strengths and limitations of the research. On the positive side, the measures used in the study were guided by a sound theoretical framework and proven reliability and validity in the South African multicultural employment context. Potential limitations of the study relate to the exploratory nature of the research design. The generalisation of results may be limited to the organisation in which the study was conducted only. The correlational design focused on exploring the strength and direction of the associations between the variables of concern to the study. Therefore, no statements about causation can be made. In light of the relatively small sample and unequal distribution of the age and race groups in the particular organisation, the study needs to be replicated with broader population groups in a wider range of occupational contexts.

\section{Conclusion}

Notwithstanding the limitations, the study could be regarded as a first step in investigating the relationship between two constructs that are recognised in the career research literature as important career meta-capacities in the career development and employability of individuals. Although exploratory in nature, the results also pointed to important differences between age and race groups in terms of their career anchors. In light of the increasingly multicultural work and uncertain career contexts in which employees have to construct their careers, it is trusted that the findings provided valuable insights that may potentially contribute to career management practices in the financial environment.

\section{Acknowledgements \\ Competing interests}

The authors declare that they have no financial or personal relationship(s) that may have inappropriately influenced them in writing this article.

\section{Authors' contributions}

R.M.O. (University of South Africa) supervised the project and assisted with the writing up of the article. M.C. (University of South Africa) wrote up the research article. F.M. (University of South Africa) collected the data and conducted the statistical analysis.

\section{References}

Beyer, J., \& Hanna, D. (2002). Building on the past: Enacting established personal identities in a new work setting. Organization Science, 13(6), 636-652. http:// dx.doi.org/10.1287/orsc.13.6.636.495

Bezuidenhout, M. (2011). The development and evaluation of a measure of graduate employability in the context of the new world of work. Unpublished master's dissertation, Department of Human Resources, University of Pretoria, Pretoria, South Africa.

Bezuidenhout, M., \& Coetzee, M. (2011). Preliminary exploratory factor analysis: Student Employability Scale. Unpublished research report, Department of Industrial and Organisational Psychology, University of South Africa, Pretoria, South Africa.

Botha, J. (2014). The relationship between adult learner self-directedness and employability attributes - An open distance learning perspective. Unpublished master's dissertation, Department of Human Resource Management, University of South Africa, Pretoria, South Africa.

Chang, C.L.H., Jiang, J.J., Klein, G., \& Chen, H.G. (2012). Career anchors and disturbances in job turnover intentions - A case study of IT professionals in Taiwan. Information \& Management, 49, 309-319. http://dx.doi.org/10.1016/j. im.2012.08.002

Chudzikowski, K. (2012). Career transitions and career success in the 'new' career era. Journal of Vocational Behavior, 81, 298-306. http://dx.doi.org/10.1016/j. jvb.2011.10.005

Clarke, M. (2008). Understanding and managing employability in changing career contexts. Journal of European Industrial Training, 32(4), 259-284. http://dx.doi org/10.1108/03090590810871379

Coetzee, M. (2014). A psychological career resources framework for contemporary career development. In M. Coetzee (ed.), Psycho-social career meta-capacities: Dynamics of contemporary career development (pp. 87-122). Dordrecht, The Netherlands: Springer International. http://dx.doi.org/10.1007/978-3-31900645-1_6

Coetzee, M., \& Bergh, Z. (2009). Psychological career resources and subjective work experiences of working adults: An exploratory study. Southern African Business Review, 13(2), 1-31.

Coetzee, M., \& De Villiers, M.A. (2010). Sources of job stress, work engagement and career orientations of employees in a South African financial institution. Southern African Business Review, 14(1), 27-57.

Coetzee, M., \& Roythorne-Jacobs, H. (2012). Career counselling and guidance in the workplace: A manual for career practitioners. (2nd edn.). Cape Town, South Africa: Juta.

Coetzee, M., \& Schreuder, A.M.G. (2008). A multi-cultural investigation of students' career anchors at a South African higher education institution. South African Journal of Labour Relations, 32(2), 45-65.

Coetzee, M., \& Schreuder, A.M.G. (2009). Using the Career Orientations Inventory (COI) for measuring career orientations in the South African organisational context. South African Journal of Industrial Psychology, 35(1), Article \#806, 13 pages. http://dx.doi.org/10.4102/sajip.v35i1.806

Coetzee, M., \& Schreuder, A.M.G. (2011). The relation between career anchors, emotional intelligence and employability satisfaction among workers in the service industry. Southern African Business Review, 15(3), 76-97.

Coetzee, M., \& Schreuder, A.M.G. (2014). Career anchors as a meta-capacity in career development. In M. Coetzee (ed.), Psycho-social career meta-capacities: Dynamics of contemporary career development (pp. 139-154). Dordrecht, The Netherlands: Springer International. http://dx.doi.org/10.1007/978-3-319-00645-1

Coetzee, M., Schreuder, A.M.G., \& Tladinyane, R. (2007). Career anchors and its relation to organisational commitment. Southern African Business Review, 11(1), 65-86.

DHET. (2014). Government Gazette Notice 380: National Scarce Skills List, Version 20 May 2014. Pretoria, South Africa: Government Printer.

Ellison, J.A., \& Schreuder, A.M.G. (2000). The relationship between career anchors, occupational types and job satisfaction of mid-career employees. Journal of Industrial Psychology, 26(2), 1-6. 
Feldman, D.C., \& Bolino, M.C. (1996). Careers within careers: Reconceptualising the nature of career anchors and their consequences. Journal of Human Resources Review, 6(2), 89-112. http://dx.doi.org/10.1016/S1053-4822(96)90014-5

Forret, M.L., \& Sullivan, S.E. (2002). A balanced scorecard approach to networking: A guide to successfully navigating career challenges. Organizational Dynamics, 31(3), 245-258. http://dx.doi.org/10.1016/S0090-2616(02)00112-2

Fugate, M., \& Kinicki, A.J. (2008). A dispositional approach to employability: Development of a measure and test of implications for employee reactions to organisational change. Journal of Occupational and Organizational Psychology, 81, 503-527. http://dx.doi.org/10.1348/096317907X241579

Hillage, J., \& Pollard, E. (1998). Employability: Developing a framework for policy analysis. Research Brief No. 85. London, UK: Department for Education and Employment.

IBM Statistical Package for Social Sciences Version 22.0 [Computer software]. (2011) Armonk, NY: IBM Corporation.

Joāo, T.F., \& Coetzee, M. (2011). Perceived career mobility and preference, job satisfaction and organisational commitment in the financial sector: An exploratory study. South African Journal of Labour Relations, 35(1), 38-60.

Mihail, D.M. (2008). Proactivity and work experience as predictors of career-enhancing strategies. Human Resource Development International, 11(5), 523-537. http:// dx.doi.org/10.1080/13678860802417668

Nazar, G., \& Van der Heijden, B.I.J.M. (2012). Career identity and its impact upon self-perceived employability among Chilean male middle-aged managers. Human Resource Development International, 15(2), 141-156. http://dx.doi.org/10.1080 /13678868.2012.664692

Ndzube, F. (2013). The relationship between career anchors and employability. Unpublished master's dissertation, Department of Industrial and Organisational Psychology, University of South Africa, Pretoria, South Africa.

Obschonka, M. (2014). Entrepreneurship as 21st century skill: Taking a developmental perspective. In M. Coetzee (ed.), Psycho-social career meta-capacities: Dynamics of contemporary career development (pp. 293-306). Dordrecht, The Netherlands: Springer International. http://dx.doi.org/10.1007/978-3-319-00645-1_16

Pato, T., \& Spira, J. (2008). SA searching in vain for 22000 accountants. Retrieved February 23, 2008, from http://beta.saica.co.za/tabid/1185/itemid/903/SA searching-in-vain-for-22-000-accountants.aspx

Pool, L., \& Sewell, P. (2007). The key to employability: Developing a practical mode of graduate employability. Education and Training, 49(4), 227-289. http://dx.doi. org/10.1108/00400910710754435

Potgieter, I.L. (2012). The development of a career meta-competency model for sustained employability. Unpublished doctoral thesis, Department of Human Resource Management, University of South Africa, Pretoria, South Africa.

Potgieter, I.L. (2014). Personality and psychosocial employability attributes as meta-capacities for sustained employability. In M. Coetzee (ed.), Psycho-socia career meta-capacities: Dynamics of contemporary career development (pp. 35-54). Dordrecht, The Netherlands: Springer International. http://dx.doi org/10.1007/978-3-319-00645-1_3
Savickas, M.L., \& Porfeli, E.J. (2012). Career Adapt-Abilities Scale: Construction, reliability, and measurement equivalence across 13 countries. Journal of reliability, and measurement equivalence across 13 countries. Journal of
Vocational Behavior, 80, 661-673. http://dx.doi.org/10.1016/j.jvb.2012.01.011

Schein, E.H. (1978). Career dynamics: Matching individual and organizational needs. Massachusetts: Addison-Wesley.

Schein, E.H. (1990). Career anchors: Discovering your real values. San Diego: CA Pfeiffer.

Schein, E.H. (1992). Career anchors and job/role planning: The links between caree planning and career development. In D.H. Montross \& C.J. Shinkman (Eds.) Career development theory and practice (pp. 207-217). Springfield, IL: Charles C. Thomas.

Schein, E.H. (1996). Career anchors revisited. Implications for career development in the 21st century. Academy of Management Executive, 1, 80-88.

Schreuder, A.M.G., \& Coetzee, M. (2011). Careers: An organizational perspective. (4th edn.). Cape Town, South Africa: Juta.

Schwartz, S.H. (1992). Universals in the content and structure of values: Theoretrical advances and empirical tests in 20 countries. In M.P. Zanna (ed.), Advances in experimental social psychology (Vol. 25, pp. 1-65). San Diego, CA: Academic Press.

South African Institute of Chartered Accountants (SAICA). (2008). The financia management, accounting and auditing skills shortage research report, 2008. Retrieve February 23, 2008, from https://www.saica.co.za/documents/Skills Report_sh.pdf

Stauffer, S.D., Maggiori, C., Froidevaux, A., \& Rossier, J. (2014). Adaptability in action Using personality, interest and values data to help clients increase their emotional social, and cognitive career meta-capacities. In M. Coetzee (ed.), Psycho-social career meta-capacities: Dynamics of contemporary career development (pp. 55-74). Dordrecht, The Netherlands: Springer International. http://dx.doi org/10.1007/978-3-319-00645-1_4

Super, D.E. (1990). A life span, life-space approach to career development. In D. Brown \& L. Brooks (eds.), Career choice and development (2nd edn., pp. 197-261). San Francisco, CA: Jossey-Bass.

Themba, M.A., Oosthuizen, R.M., \& Coetzee, M. (2012). Exploring socio-demographic differences in career maturity in the South African military. South African Journa of Labour Relations, 36(1), 8-30.

Tones, M., Pillay, H., \& Kelly, K. (2011). The link between age, career goals and adaptive development for work-related learning among local government employees. Journal of Career Assessment, 19(1), 92-110. http://dx.doi. org/10.1177/1069072710382618

Van der Heijde, C.M. (2014). Employability and self-regulation in contemporary careers. In M. Coetzee (ed.), Psycho-social career meta-capacities: Dynamics of contemporary career development (pp. 7-18). Dordrecht, The Netherlands: Springer International. http://dx.doi.org/10.1007/978-3-319-00645-1_1

Van der Heijde, C.M., \& Van der Heijden, B.I.J.M. (2006). A competence-based and multidimensional operationalisation and measurement of employability. Human Resources Management, 45(3), 449-476. http://dx.doi.org/10.1002/hrm.20119

Wils, L., Wils, T., \& Tremblay, M. (2010). Toward a career anchor structure: An empirical investigation of engineers. Industrial Relations, 65(2), 236-256. http:// dx.doi.org/10.7202/044301ar 